\title{
Eggshell membrane protein can be absorbed and utilised in the bodies of rats
}

\author{
Ryosuke Matsuoka* ${ }^{*}$, Hitoshi Kurihara, Hiroko Yukawa and Ryou Sasahara
}

\begin{abstract}
Objective: Eggshell membranes, the thin film lining the insides of eggshells, are constituted mostly from protein (eggshell membrane protein, ESM-P). The digestibility and dietary net protein utility of ESM-P are not known. ESM-P functions as a barrier to prevent foreign matter from reaching the egg white and yolk, so it would be expected not to decompose easily by digestion when ingested. We therefore prepared a hydrolysate of the membrane (ESM-H). In this study, we assessed the digestibility and net protein utility of ESM-P and ESM-H in rats.

Results: The digestibility of ESM-P and ESM-H were $87.0 \%$ and $94.8 \%$, respectively, significantly lower than that of casein (98.5\%). The net protein utility values were $84.7 \%$ and $84.6 \%$, respectively, significantly higher than that of casein (75.1\%). Digestibility was significantly higher for ESM-H than for ESM-P, but there was no significant difference in net protein utility between ESM-P and ESM-H. These results demonstrated that more than 80\% of ESM-P or ESM-H is absorbed and utilised in the bodies of rats.
\end{abstract}

Keywords: Eggshell membrane, Protein, Hydrolysate, Net protein utilisation, Rats

\section{Introduction}

The eggshells and eggshell membranes of hens' eggs are little used potential dietary resources. Eggshells are known to be a source of calcium, which can increase bone density [1]. The eggshell membrane, a thin film lining the inside of the eggshell, is constituted mainly of protein. Eggshell membranes have been used as carbon dioxide and heavy metal absorbers [2,3], and also in sauces such as soy sauce [4]. They have also been reported to have a skin-moisturising effect and to ameliorate knee joint pain $[5,6]$. To clarify these and other potential health functions, it is important to elucidate the action mechanisms of eggshell membrane protein (ESM-P). A necessary first step is to establish that the protein is digested, absorbed and utilised in the body. However, the digestibility and net protein utility of dietary ESM-P are not known.

Collagen is another protein reported to have a skinmoisturising effect and to ameliorate knee joint pain. Collagen is known not to be utilised in vivo independently because it contains little tryptophan [7]. It has been speculated that collagen exerts its health functions after absorption following its consumption as part of routine protein intake. In contrast, it is likely that ESM-P will be absorbed and utilised in the body because of its 100\% amino acid score.

It has been reported that ESM-P include collagen type $\mathrm{I}, \mathrm{V}$, and $\mathrm{X}$, and protein derived from egg white $[8,9]$. The net protein utility values of proteins in white have been reported to be higher than those of other protein sources [10].

The aim of this study was to assess the digestibility and net protein utility of ESM-P. Because ESM-P functions as barrier to prevent foreign matter from reaching the egg white and yolk, we thought it likely that the protein would not be easily decomposed by digestion when ingested. We therefore prepared a hydrolysate of eggshell membrane (ESM-H), using enzymatic hydrolysis to convert it to low molecular weight peptides, and assessed its digestibility and net protein utility in addition to those of ESM-P. 


\section{Main text \\ Methods \\ Materials}

Casein was purchased from Oriental Yeast Co., Ltd. (Tokyo). ESM-P and ESM-H were obtained from Kewpie Corporation (Tokyo). ESM-H was prepared by the alkaline protease digestion of ESM-P. After enzyme inactivation at $90{ }^{\circ} \mathrm{C}$, the hydrolysate was spray-dried ready for testing [11]. The amino acid composition of the samples was measured by Japan Food Research Laboratories (Tokyo; Table 1). Their protein content was calculated by multiplying the nitrogen content determined by the Dumas method [12] by 6.25. The protein content/100 g of casein, ESM-P, and ESM-H were $87.4 \mathrm{~g}, 99.7 \mathrm{~g}$ and $75.4 \mathrm{~g}$, respectively. The mean molecular weight of ESM-H was about 855 .

\section{Animals and diets}

Eight-week-old male Sprague Dawley rats (245-275 g) were used $(n=6)$. The animals were kept in metabolic cages (Toyo-Riko Co., Ltd., Tokyo) at $23.1{ }^{\circ} \mathrm{C}$, with $50 \% \pm 2 \%$ humidity and a 12-h light (8:00-20:00)/dark cycle.

Test diets were prepared according to the American Institute of Nutrition (AIN)-76 formulation [13]. They included casein, ESM-P, or ESM-H at $10 \%$. The other ingredients were as follows: cornstarch, 15\%; cellulose, $5 \%$; mineral mixture (AIN-76), 3.5\%; vitamin mixture

Table 1 Amino acid composition of casein, ESM-P or ESM-H (g/100 g)

\begin{tabular}{lccc}
\hline & Casein & ESM-P & ESM-H \\
\hline Ile & 4.65 & 3.22 & 2.46 \\
Leu & 8.35 & 4.54 & 3.57 \\
Lys & 7.23 & 3.26 & 2.40 \\
Met & 2.47 & 3.71 & 2.85 \\
Cys & 0.39 & 9.73 & 5.95 \\
Phe & 4.56 & 1.54 & 1.23 \\
Tyr & 4.97 & 1.71 & 1.47 \\
Thr & 3.83 & 5.50 & 4.22 \\
Trp & 1.10 & 3.27 & 2.39 \\
Val & 5.83 & 6.92 & 5.28 \\
His & 2.70 & 3.95 & 2.86 \\
Arg & 3.33 & 7.13 & 5.38 \\
Ala & 2.73 & 2.59 & 2.21 \\
Asp & 6.35 & 8.19 & 6.37 \\
Gul & 19.7 & 12.4 & 9.47 \\
Gly & 1.69 & 5.84 & 4.50 \\
Pro & 9.48 & 9.36 & 7.48 \\
Ser & 5.09 & 5.21 & 4.02 \\
\hline
\end{tabular}

ESM egg shell membrane
(AIN-76), 1\%; corn oil, 5\%; choline bitartrate, $0.2 \%$; and sucrose to $100 \%$. A protein level of $10 \%$ was used in this experiment, as described in previous studies [14, 15], because it is easier to assess net protein utility in a lowprotein condition, and it allowed the results to be compared with previous data. The animals were pair-fed one of these three diets for 10 days, with ad libitum access to distilled water. We did not check water consumption. But it was reported that positive relation between dietary intake and water consumption [16]. Their faeces and urine were collected for the last 5 days of the test. A fourth group that received no protein was used to calculate the metabolic nitrogen levels for the analysis: the faecal and urinary metabolic nitrogen levels per 5 days for this group were $16.9 \pm 0.7 \mathrm{mg}$ and $26.2 \pm 1.6 \mathrm{mg} / 5$ day, respectively. The rats were euthanized by $\mathrm{CO}_{2}$ gas.

This experiment was conducted in accordance with the Guidelines for Animal Experiments, Law No. 105 and Notification No. 6, of the Government of Japan and the animal experiment rules of the Research and Development Headquarters. This experiment was approved by Ethics committee of Kewpie corporation $R \& D$ division (Reference and Permission No. 17-06). The experiment was performed from 5 to 22 December 2017.

\section{Analysis}

Faecal and urinary protein contents were calculated by measuring the nitrogen $(\mathrm{N})$ content using the Dumas method [12] and multiplying this by the protein conversion factor 6.25. Protein efficiency, digestibility and net protein utility were calculated from the following formulae [17]:

$$
\begin{aligned}
& \text { Digestibility } \\
& =[\text { ingested } \mathrm{N}-(\text { faecal } \mathrm{N}-\text { faecal metabolic } \mathrm{N})] \\
& \quad / \text { ingested } \mathrm{N} \times 100 \%
\end{aligned}
$$

Net protein utility $=$ Digestibility

- (ingested $\mathrm{N}-$ urinary metabolic $\mathrm{N}$ )

/ingested $\mathrm{N} \times 100 \%$

\section{Statistical analysis}

Test results are expressed as mean $\pm \mathrm{SE}$. The statistical analyses used Tukey's test and were performed using SPSS ver. 20 software (Japan IBM Co., Ltd., Tokyo). Differences were considered statistically significant when the $p$ value was less than $5 \%$.

\section{Results \\ Growth parameters}

Table 2 summarises the growth parameters. No significant differences were detected in dietary intake among the three groups. The ESM-P and ESM-H 
Table 2 Growth variables, faecal and urine nitrogen content in rats fed a diet containing casein, ESM-protein or ESMhydrolysate

\begin{tabular}{lccc}
\hline & Casein & ESM-protein & ESM-hydrolysate \\
\hline Initial body weight $(g)$ & $277 \pm 3$ & $277 \pm 3$ & $277 \pm 3$ \\
Final body weight (g) & $305 \pm 2^{\mathrm{a}}$ & $286 \pm 6^{\mathrm{b}}$ & $296 \pm 2^{\mathrm{ab}}$ \\
Body weight gain (g/day) & $2.76 \pm 0.22^{\mathrm{a}}$ & $0.868 \pm 0.468^{\mathrm{b}}$ & $1.87 \pm 2.4^{\mathrm{ab}}$ \\
Food consumption (g/day) & $19.9 \pm 0.0$ & $20.0 \pm 0.4$ & $20.1 \pm 0.7$ \\
Food efficiency* & $0.136 \pm 0.011^{\mathrm{a}}$ & $0.0421 \pm 0.0236^{\mathrm{b}}$ & $0.0982 \pm 0.0177^{\mathrm{ab}}$ \\
Faecal weight (dry g/5 days) & $8.57 \pm 0.08$ & $9.90 \pm 0.73$ & $9.09 \pm 0.40$ \\
Urine volume (mL/5 days) & $62.8 \pm 13.0^{\mathrm{a}}$ & $26.3 \pm 8.4^{\mathrm{b}}$ & $61.1 \pm 3.5^{\mathrm{a}}$ \\
Faecal nitrogen (mg/5 days) & $40.8 \pm 0.9^{\mathrm{a}}$ & $226 \pm 17^{\mathrm{b}}$ & $101 \pm 5^{\mathrm{c}}$ \\
Urine nitrogen (mg/5 days) & $397 \pm 12^{\mathrm{a}}$ & $65.0 \pm 10.6^{\mathrm{b}}$ & $187 \pm 12^{\mathrm{c}}$ \\
\hline
\end{tabular}

Mean \pm standard error (SE) of six rats. Superscript letters indicate a significant difference (Tukey's test, $p<0.05$ )

ESM egg shell membrane

${ }^{*}$ Food efficiency: body weight gain (g/day)/food consumption (g/day)

groups showed significantly lower weight gain than the casein group. Food efficiency was significantly higher in the casein group than in the ESM-P group, but there was no significant difference between the ESM-P and ESM-H groups.

\section{Faecal and urine nitrogen content}

Table 2 summarises the faecal amount, urine volume and faecal and urinary nitrogen content for the three groups. No significant difference in faecal excretion was detected among the groups. Urinary excretion was significantly lower in the ESM-P group than in the casein and ESM-H groups. Faecal and urinary nitrogen content were significantly higher in the ESM-P and ESM-H groups than in the casein group, and significantly higher in the ESM-P group than in the ESM-H group.

\section{Digestibility and net protein utility}

Figure 1 summarises the digestibility and net protein utility. The digestibility of ESM-P and ESM-H were 87.0\% and $94.8 \%$, respectively, significantly lower than that of casein $(98.5 \%)$. The net protein utility values were $84.7 \%$ and $84.6 \%$, respectively, significantly higher than that of casein (75.1\%). Digestibility was significantly higher for ESM-H than for ESM-P, but there was no significant difference in net protein utility between them.

\section{a}

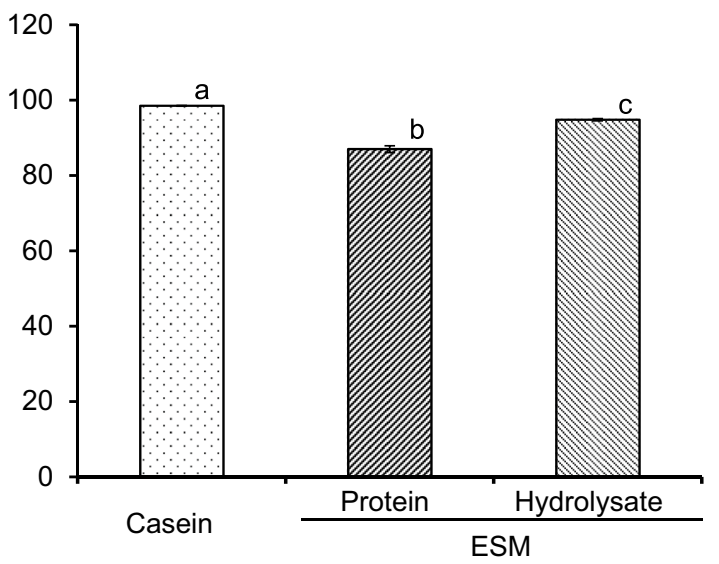

b

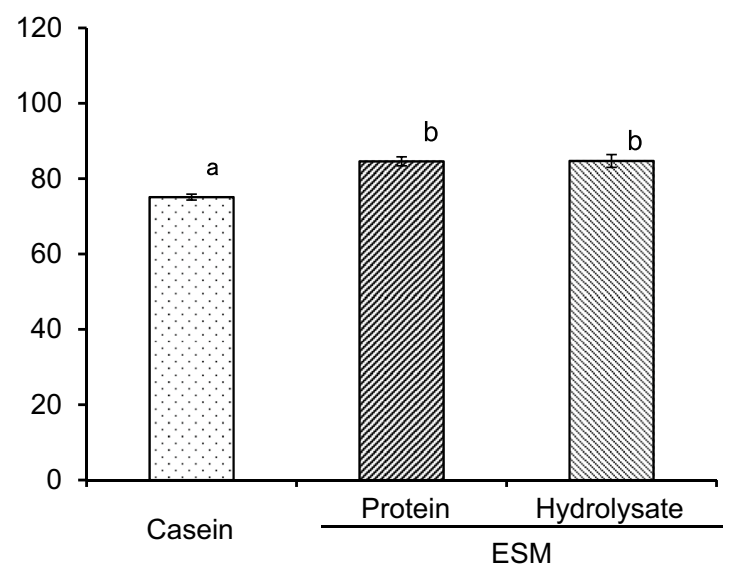

Fig. 1 Digestibility (a) and net protein utilisation (b) of eggshell membrane protein (ESM-P) or hydrolysate (ESM-H) in rats. Mean \pm S.E. for six rats. Superscript letters indicate a significant difference (Tukey's test, $p<0.05$ ) 


\section{Discussion}

The results of this study demonstrated that more than $80 \%$ of ESM-P is absorbed and utilised in vivo. Followup test results showed that the digestibility and net protein utility of ESM-P were $88.8 \%$ and $82.4 \%$, and those of ESM-H were $95.1 \%$ and $84.7 \%$, respectively (unpublished data). These values were similar to the results of the present study, confirming its reproducibility.

The digestibility and net protein utility values of ESM-P and ESM-H were lower than representative values for white proteins [10]. This may be because of the low content of the essential amino acids phenylalanine + threonine and leucine (Table 1). However, the net protein utility of ESM-P was higher than that of casein, suggesting that the lower absorption of the ESM proteins was due to their physicochemical structures rather than the low content of an essential amino acid. Indeed, their digestibility was significantly lower than that of casein.

Although total nitrogen excretion (faecal + urea) of the casein group was higher than that of the ESM-P and ESM-H groups, the body weight of the casein group was higher than that of the ESM-P and ESM-H groups (Table 2, Fig. 1).

We believe that total nitrogen excretion and NPU affects the body's protein content. Except for water content, animal bodies consist mainly of protein and fat. It has been reported that egg white protein increases the amount of body protein and decreases the amount of body fat compared with casein in rats [18]. ESM included protein derived from egg white [9]. It was believed that the reason that the body weights of ESM-P and ESM-H groups were lower than that of the casein group was that the body fat in the ESM-P and ESM-H groups was lower than that in the casein group.

ESM-P has been reported to have a skin-moisturising effect and to ameliorate knee joint pain $[5,6]$. Similar effects have been reported for hyaluronic acid [19, 20]. Hyaluronic acid is thought to be absorbed after being digested into low molecular weight molecules in the digestive tract by the action of intestinal microbiota [21]. Biokinetic tests have shown it is then delivered to the skin and the knee joints [22, 23].

Hyaluronic acid is a saccharide, but there are proteins that are known to exert similar effects. Collagen has been reported to have similar effects to those of ESM-P. However, collagen can hardly be absorbed independently because of its low content of tryptophan, an essential amino acid. Collagen contains abundant hydroxyproline [7], whereas ESM-P contains collagen [9]. Furthermore, because collagen is a skin and knee joint component, its absorption appears to be an action for supplementing insufficient collagen levels. It is therefore likely that ESM-P exerts one of its effects via a same mechanism.
Clarification of this mechanism is likely to require an assessment of ESM-P biokinetics.

In the present study, urine volume was lower in the ESM-P group rats $(26.3 \pm 8.4 \mathrm{~mL} / 5$ days $)$ compared with the volumes for those fed ESM-H and casein. Dietary intake and net protein utilisation were same in the ESM-P and ESM-H groups, but body weight was lower in the ESM-P group than in the ESM-H. Thus, the reason for the lower urine volume in the ESM-P group may have been lower body water content and water intake in this group compared with the ESM-H group. In a previous study, we found a similar urine volume in rats fed milk whey $(27.3 \pm 4.3 \mathrm{~mL} / 5$ days $)$ [10]. In that study, the nitrogen content in the urine was $275 \pm 26 \mathrm{mg} /$ day [10]; in the present study, the urine nitrogen content in the ESM-H group was $187 \pm 12 \mathrm{mg} /$ day, suggesting that there was no problem in the nitrogen excretion capacity in the rats fed ESM-P.

There are subjects in utilisation of ESM-P in foods, etc. expecting its functions for health. For use in foods, it may be necessary to digest eggshell membrane into low molecular weight molecules for efficient absorption, given its lower digestibility than casein [5], and to improve its flavour and/or physical properties. It may be possible to utilise the protein in supplements, although this would depend on its effective dose.

\section{Conclusions}

In this study, ESM-H showed higher digestibility than ESM-P, but their net protein utility was nearly the same. It is therefore likely that their net protein utility is influenced by their amino acid composition rather than their digestibility. The potential use of ESM-P and ESM-H in food and health products has been little studied. The results of this study should contribute to consideration of ESM-P and ESM-H as a new functional food ingredient.

\section{Limitations}

Clarification of this mechanism is likely to require an assessment of ESM-P biokinetics. It would be necessary first to assess the absorbability and receptor-binding capacity of ESM-P in the small intestine, for example, to establish its action in the digestive tract.

\section{Abbreviations}

ESM-P: eggshell membrane protein; ESM-H: eggshell membrane hydrolysate; AIN: American Institute of Nutrition.

\section{Acknowledgements}

We thank Prof. Michihiro Sugano for providing technical advice about this experiment. We thank Enago (http://www.enago.jp) for the English language review. 


\section{Authors' contributions}

$\mathrm{RM}$ wrote the manuscript. RM, HK, YH and RS participated in the experimental work and collected and analysed data. All authors read and approved the final manuscript.

\section{Funding}

No funding.

\section{Availability of data and materials}

All data generated or analysed during this study are included in this published article.

\section{Ethics approval and consent to participate}

This experiment was conducted in accordance with the Guidelines for Animal Experiments, Law No. 105 and Notification No. 6, of the Government of Japan and the animal experiment rules of the Research and Development Headquarters, Kewpie Corporation, with approval (Permission No. 17-06).

\section{Consent for publication}

Not applicable.

\section{Competing interests}

The authors declare that they have no competing interests.

Received: 26 March 2019 Accepted: 4 May 2019

Published online: 09 May 2019

\section{References}

1. Sakai S, Hien VTT, Tuyen LD, Duc HA, Masuda Y, Yamamoto S. Effects of eggshell calcium supplementation on bone mass in postmenopausal Vietnamese women. J Nutr Sci Vitaminol. 2017:63:120-4.

2. Banergee A, Panda S, Sidhantha M, Chakravati S, Chaudhuri B, Bhattaharjee S. Utilisation of eggshell membrane as an adsorbent for carbon dioxide. Int J Glob Warm. 2010;2:252-61.

3. Suyama K, Fukazawa Y, Umetsu Y. A new biomaterial, hen eggshell membrane, to eliminate heavy metal ion from their dilute waste solution. Appl Biochem Biotechnol. 1994;45-46:871-9.

4. Horiike S. Efficacy of health food, feature and usage of Ransyo. New Food Ind. 2000;42:44-8 (in Japanese)

5. Yoo JH, Kim JK, Yang HJ, Park KM. Eggshell membrane hydrolysates on the UVB-radiation-induced wrinkle formation in SKH-1 hairless mice. Korean J Food Sci Anim Resour. 2015;35:58-70.

6. Wedekind KJ, Ruff KJ, Atwell CA, Evans JL, Bendele AM. Beneficial effects of natural eggshell membrane (NEM) on multiple indices of arthritis in collagen-induced arthritic rats. Mod Rheumatol. 2017;27:838-48.

7. Eastoe JE. The amino acid composition of mammalian collagen and gelatin. Biochem J. 1955;61:589-600.

8. Rath NC, Liyanage R, Makkar SK, Lay JO Jr. Protein profiles of hatchery egg shell membrane. Proteome Sci. 2017;15:4.

9. Nys Y, Gautron J, McKee MD, Gautron JM, Hincke MT. Biochemical and functional characterization of eggshell matrix proteins in hens. World's Poult Sci J. 2001;57:401-13.
10. Matsuoka R, Takahashi Y, Kimura M, Masuda Y, Kunou M. Heating has no effect on the net protein utilisation from egg whites in rats. Sci World J. 2017:2017:6817196.

11. Tanaka R, Yukawa H, Sasahara R. Eggshell membrane hydrolysate, Nippon Tokkyo Koho. 2017; P2017-81076 (in Japanese)

12. Stitcher JE, Jolliff CR, Hill RM. Comparison of Dumas and Kjeldahl methods for determination of nitrogen in faeces. Clin Chem. 1969;15:248-54.

13. American Institute of Nutrition. Report of the American Institute of Nutrition ad hoc committee on standards for nutritional studies. J Nutr. 1977;107:1340-8

14. Morrison AB, Campbell JA. Evaluation of protein in foods V. factors influencing the protein efficiency ratio of foods. J Nutr. 1960;70:112-8.

15. Donatucchi DA, Liener IE, Gross CJ. Binding of navy bean (Phaseolus vulgaris) lectin to the intestinal cells of the rats and its effect on the absorption of glucose. J Nutr. 1987;117:2154-60.

16. Cizek LJ, Nocenti MR. Relationship between water and food ingestion in the rat. Am J Physiol. 1965;208:615-20.

17. Van Dael $P$, Kastenmayer P, Clough J, Jarret AR, Barclay DV, Maire JC. Substitution of casein by $\beta$-casein or of whey protein isolate by a-lactalbumin does not affect mineral balance in growing rats. J Nutr. 2005;135:1438-43.

18. Matsuoka R, Shirouchi B, Umegatani M, Fukuda M, Muto A, Masuda Y, Kunou M, Sato M. Dietary egg white protein increases body protein mass and reduces body fat mass through an acceleration of hepatic $\beta$-oxidation in rats. Br J Nutr. 2017;118:423-30.

19. Kawada C, Yoshida T, Yoshida H, Matsuoka R, Sakamoto W, Odanaka W, Sato T, Yamasaki T, Kanemitsu T, Masuda Y, Urushibata O. Ingested hyaluronan moisturizes dry skin. Nutr J. 2014;11(13):70.

20. Tashiro T, Seino S, Sato T, Matsuoka R, Masuda Y, Fukui N. Oral administration of polymer hyaluronic acid alleviates symptoms of knee osteoarthritis: a double-blind, placebo-controlled study over a 12-month period. Sci World J. 2012;2012:167928.

21. Kimura M, Maeshima T, Kobota T, Kurihara H, Masuda Y, Nomura Y. Absorption of orally administered hyaluronan. J Med Food. 2016;19:1172-9.

22. Oe M, Mitsugi K, Odanaka W, Yoshida H, Matsuoka R, Seino S, Kanemitsu T, Masuda Y. Dietary hyaluronic acid migrates into the skin of rats. Sci World J. 2014;2014:378024.

23. Balogh L, Polyak A, Mathe D, Kiraly R, Thuroczy J, Terez M, Janoki G, Ting Y, Bucci LR, Schaus AG. Absorption, uptake and tissue affinity of high molecular weight hyaluronan after oral administration in rats and dogs. J Agric Food Chem. 2008;56:10582-93.

\section{Publisher's Note}

Springer Nature remains neutral with regard to jurisdictional claims in published maps and institutional affiliations.

Ready to submit your research? Choose BMC and benefit from

- fast, convenient online submission

- thorough peer review by experienced researchers in your field

- rapid publication on acceptance

- support for research data, including large and complex data types

- gold Open Access which fosters wider collaboration and increased citations

- maximum visibility for your research: over $100 \mathrm{M}$ website views per year

At $\mathrm{BMC}$, research is always in progress.

Learn more biomedcentral.com/submissions 